\title{
WHICH INTERNAL FACTORS DRIVE COMPANIES TO SOCIAL REPORTING? AN EMPIRICAL STUDY FROM A DEVELOPING COUNTRY PERSPECTIVE
}

\author{
Ashok Chakraborty*
}

\begin{abstract}
Research Aim: This study examines the influence of firms' internal factors and the impact of a statutory regulatory order on the extent of corporate social reporting by banking firms in Bangladesh in the period from 2011 to 2015.

Design/Methodology/Approach: Besides using content analysis to construct a social disclosure index, multivariate regression analysis was performed to test a number of hypotheses related to the key variables of the study.

Research Findings: The descriptive statistics of the social reporting disclosure index do not show a notable impact of the statutory regulatory order on the extent of firms' social reporting. The study found that board meetings and board expertise have a significant positive impact on firms' social reporting, while firm size is negatively associated with firms' social reporting; thus, meaning that comparatively smaller firms perform better in terms of social reporting. However, no significant impact is found for board size and firm network on firms' social reporting.
\end{abstract}

Theoretical contribution/Originality: The study has contributed theoretical aspects about firms' different internal factors and, particularly, how legal arrangements like SRO can be applied by the government to motivate a firm to undertake corporate social activities and disclosures. The application of resource dependence theory to CSR has been further fortified with this investigative study.

Practitioner/Policy Implication: The empirical result implies that as CSR is practiced voluntarily in Bangladesh, such policies of government like tax exemption on CSR expenditure has not had much of an impact.

Research Limitation: This study can be investigated with multi-industry data to further explore industry variations, but, due to poor and inconsistent CSR reporting of other industries in Bangladesh, only listed firms in the banking industry have been included to obtain appropriate results and findings.

Type of Manuscript: Research Paper.

Keywords: Corporate Social Reporting, Internal Factors, Regulatory Impact, Banking Industry.

JEL Classification: M14

\footnotetext{
*Corresponding Author: Ashok Chakraborty is an Assistant Professor at the Department of Business Administration, Ranada Prasad Shaha University, Shytalakhya, Narayanganj1400, Bangladesh. Email: ashokdu88@gmail.com
} 


\section{Introduction}

Corporate social reporting is becoming more powerful and has a crucial impact on the decision-making of external shareholders regarding a firm. Investors are now more concerned about firms' social behaviour through corporate social reporting while making their investment decisions (Aguilera et al., 2006). As Bangladesh is emerging as a developing economic nation, stakeholders' expectation of firms about quality nonfinancial disclosures like social reporting are also increasing. However, there is a huge variation between developed countries and developing countries like Bangladesh in terms of the volume and quality of disclosures. Although a substantial number of firms are found to provide disclosures about their corporate social activities, there is a variation in terms of quality (Habek \& Wolniak, 2015).

Different pressure groups are emerging that demand that firms will be responsible for the impacts they have on the social, political, and ecological environments (Azim et al., 2011). The level of Corporate Social Responsibility (CSR) expenditure and performance varies from firm to firm. In a developing country like Bangladesh a substantial variation in the CSR disclosures and disclosure is noticeable among firms, which creates a question as to which factors are responsible for such variation. No significant research is found addressing this issue in the context of Bangladesh. There are also weaknesses in the regulations from authoritative bodies to facilitate corporate social reporting.

In 2011, a notable attempt was made by means of a Statutory Regulation Order (SRO) from the National Board of Revenue (NBR), Bangladesh through which tax exemption was provided on the corporate social responsibility expenditure made by firms. This SRO stated that any company would be exempted from income tax at the rate of 10 per cent for the actual costs incurred for corporate social responsibility. Several clauses were included within the SRO like companies have to pay employees regularly, must have a waste treatment plant, must comply with the labour code, and mandatory submission of CSR work plan to the NBR, etc. Beside these clauses, the NBR also mentioned twenty-two (22) specific areas of CSR expenditure on which companies need to expend to be eligible for tax exemption. It is very interesting to determine whether or not, after maintaining all these rules and restrictions, companies have increased their CSR expenditure to grasp the tax exemption opportunity. Hence, one of the purposes of this study is to understand the regulatory impact of this SRO over the corporate social reporting status of the firms. On the other hand, a number of internal factors related to the firm's governance and structure are supposed to 
have a driving impact on the extent and quality of corporate social reporting disclosures. The study selected listed banking firms of Bangladesh due to their diverse disclosure practice. Krasodomoska (2015) noted that banking firms disclose CSR information in a diverse manner with an extensive focus on community involvement. As far as corporate social responsibilities are concerned, the banking sector is considered to be the most successful sector (Sarker, 2000). Most of the banks operating in Bangladesh are listed on the capital market (Das et al., 2015).

The main focus of the study is the impact of the government SRO in relation to the CSR expenditure. To date, this is still a subject of investigation as no paper has uncovered the issue or determined which governance and firm internal factors work as catalysts in ascertaining the degree of firms' CSR activities and disclosure level. Hence, this study explores the internal dynamics of firms that influence their social reporting status and passes a signal to the relevant authoritative bodies about the urgency of rules and regulations to make firms more socially responsible.

The study aims to provide a deeper insight into the diverse internal factors of firm and regulatory impact on corporate social performance and disclosure. The specific research objectives are: (i) to determine the impact of the Statutory Regulation Order (SRO) by the National Board of Revenue (NBR), Bangladesh in 2011 on Corporate Social Reporting (CSR) performance and disclosures by the listed banking firms in Bangladesh, and (ii) to determine whether certain specific internal factors have a significant impact on the level of CSR activities and disclosures.

\section{Review of Literature}

The Resource Dependence Theory (RDT) best describes the determining factors related to the corporate social responsibility activities and disclosures, as it studies the impact of external resources on the operation and behaviour of an organisation. As a business operates in society, and also collects resources from the society, dependence on external resources can be one of the dominant catalysts behind initiating CSR disclosures. Such dependence on external resources and the adoption of firms' strategies and tactical management policies are marked as a hallmark of the resource dependence theory (Davis \& Cobb, 2010).

For investigating the impact of the Statutory Regulatory Oder (SRO) and firms' governance factors on voluntary disclosures like CSR, RDT provides an effective theoretical background. Hillman et al. (2009) state that the resource dependence theory recognises the impact of particular 
external factors on firms' behaviours, and how managers act in maintaining inter-organisational relationships with the boards and stakeholders while taking the political actions and executive succession of companies into consideration. There may be different catalysing factors that contribute in determining the degree of corporate social reporting. Imam (2000) points out that although CSR practices vary from a developed country to a developing country, most of the CSR studies have been conducted from the perspective of a developed country (see Gray et al., 2001; Deegan et al., 2002; Paul et al., 2006). That is why this study from Bangladesh perspective is pertinent for other developing countries. Industry variation is another factor that causes a difference in corporate social reporting among different industries (Gray et al., 2001).

Existing research has mainly concentrated on how CSR committees influence CSR disclosures (Kolk \& Pinkse, 2010). However, some government initiatives may also influence and motivate companies to go for more CSR activities as well as to report those activities to the general stakeholders. Although many empirical studies have focused on the impact of mandatory regulations by governments on CSR activities and disclosures, it is high time to empirically determine how governments can motivate companies to increase their CSR activities by introducing different rules and orders like tax exemption on CSR expenditure. Nevertheless, mandatory regulation alone is not enough to ensure better CSR practice, governments should consider different preferential treatments with permitting, monitoring or in some cases through deregulation (Glachent, 2002). Esa and Zahari (2016) note that it is the increased awareness about corporate accountability that has contributed to the rise of interest in corporate social disclosures.

Different internal factors related to corporate governance and the financial performance of companies need to be examined in the context of social reporting, particularly from a developing country perspective. Das et al. (2015) found a gap in both the corporate governance and CSR literature due to the paucity of research works in emerging economies. One important variation between developed and developing countries is that, in developed countries, the stakeholders' groups are very strong at creating pressure on companies to disclose more non-financial information like social, environmental, sustainability, etc., which is almost absent in the developing country perspective. Belal and Owen (2007) identify stakeholders' pressure as an important issue for corporate social reporting.

There are a number of internal factors that are also related to corporate governance, company characteristics, and financial 
performance. Identifying the factors that drive companies to disclose more social information is the real contribution to the CSR literature (Owen, 2005). A significant number of studies have investigated the relationship between corporate size and corporate social responsibility disclosures of which many found a significant positive relationship between company size and the CSR disclosure level (Naser \& Hassan, 2013). However, most of these studies are in developed country settings and do not focus on government soft regulations like tax exemptions on CSR expenditure.

\subsection{Corporate Social Reporting Practices in Bangladesh}

Bangladesh is one of the rapid economically emerging countries in the world where non-financial reporting like corporate social reporting is also going through an important phase. There is an increasing expectation from different stakeholders that companies should be responsible and accountable for the impacts they have on the society and the environment (Azim et al., 2009). After the independence of Bangladesh, there was a lack of regulations regarding non-financial reporting like corporate social reporting. Family dominance on the boards of the companies is very common in Bangladesh, which has resulted in poor voluntary reporting disclosure practices. Choudhury (2008) remarks in his study that many companies have family dominance and an informal control mechanism.

In addition, the Companies Act 1994 (Government of Bangladesh, 1994) does not contain any provision regarding corporate social reporting. In examining the annual reports of 40 listed companies in the Dhaka Stock Exchange for the period of 1996-1997, Imam (2000) found a very poor level of disclosure related to community, environment, and customers, which was not adequate to discharge social responsibilities. Hossain et al. (2006) found that, on average, only 8.33 per cent of the Bangladeshi companies provide social and environmental disclosures in annual reports. One important dimension of corporate social reporting in Bangladesh is that structured and standalone corporate social reporting is lacking. Most of the companies disclose their social and environmental disclosures either in a separate segment or in the director's report.

Belal (2001) mentions that the quality of disclosed information is very low and that most disclosures are descriptive in nature. Imam (2000) also argues that the absence of an independent audit raises big question about the credibility of the information disclosed in social reporting. In most of the studies, annual reports were used as the primary source to analyse the extent of corporate social reporting. Belal 
and Owen (2007), in an interview-based study conducted on 21 managers in Bangladesh, reveal that the key motivation behind corporate social reporting in Bangladesh is to satisfy the principal stakeholder groups. Another notable dimension of corporate social reporting in Bangladesh is that most disclosures cover the philanthropic activities performed by the companies and that few qualitative disclosures are found focusing on the environment and ecology. Belal and Cooper (2011) mention that many companies in Bangladesh stay away from sensitive social disclosure issues like child labour, equal opportunities, and poverty alleviation.

\subsection{Development of Hypothesis}

The study is based on several hypotheses that are linked to the identification of the relationship between a company's internal factors and the level of CSR disclosures. A few variables have been taken into consideration that are expected to have a significant impact on the research objectives and are catalysts to form hypotheses.

\subsubsection{Board Size}

There may be a kind of impact of the board size of a company on the level of corporate social responsibility activities and disclosures. The board is expected to play a crucial role in determining the strategies and policies regarding the inter relationships and inter dependence between the company and the external stakeholders. Although the agency theory has more dominance in studying areas related to the board of directors, the Resource Dependence Theory (RDT) has the greatest research interest in this arena (Hillman et al., 2009). Hermalin and Weisbach (2003) found a positive relationship between the size of the board of directors and the extent of CSR disclosures. In contrast, Chen and Jaggi(2000) mention that a large number of board members may diminish the effectiveness of the board resulting in poor corporate social reporting. In 2006, there was a corporate governance code for listed companies for a minimum of 5 board members and a maximum of 20. This study assumes that board size will influence a company's corporate social activities and disclosures. The study hypothesises as follows:

$H_{1}$ : There is a significant association between board size and the level of CSR disclosures.

\subsubsection{Company Network}

It is very rare in the CSR literature to find any evidence where the company's network in terms of the number of branches has been tested 
with the CSR disclosures. The company network can be viewed from the resource dependence theory as companies need to depend on the external environment for different resources. So, having a wider and stronger network plays a crucial role in this regard. The study assumes that a significant relationship may exist between the number of branches of banking companies and the level of social activities performed. It is also assumed that a Bank with more branches usually has wider network which helps to reach it to the more potential stakeholders, as well as to conduct more social responsibilities.

$\mathrm{H}_{2}$ : There is a significant positive association between the company's network and the level of corporate social reporting disclosure.

\subsubsection{Board Meeting}

The number of board meetings is considered to be one of the most powerful tools to represent the activity of the board of a company (Velte, 2017). Board members are expected to sit together to form different strategic programmes and policies concerning how to remove the information and expectation gap between the external stakeholders and the company through better and quality social disclosures. The study hypothesises that the number of board meetings has a positive impact on the level of corporate social reporting. Following is the hypothesis regarding this variable:

$H_{3}$ : There is a significant positive association between board meetings and the level of corporate social disclosure.

\subsubsection{Board Expertise}

Board expertise can be a key internal factor of a company that may have a potential impact on a company's social performance and reporting. The Resource Dependence Theory (RDT) also supports that the expertise of board members is crucially important for strategic dealing with external parties and environments, which provide valuable resources to the companies. Kor and Misangye (2008) uses the collective industry experience of the board members of the sample companies in their research where the resource dependence theory was applied as the theoretical background. Velte (2017) mentions that the variable board expertise is less commonly tested in the empirical studies related to social reporting. Practically it is difficult to measure the expertise of a board member. Professional and academic degrees like Chartered Accountancy, ACCA, CIMA, and PhD have been used as determinants of board expertise on the grounds that board members with these degrees are 
supposed to be professionally and strategically sound compared to other members to accomplish better corporate social activities and reporting.

$H_{4}$ : There is a positive association between board expertise and the level of CSR disclosure.

\subsubsection{Company Size}

A relationship can be expected between company size and the level of corporate social responsibility performance and disclosures. Several studies (Hamid 2004; Reverte 2009; Tagessonet al., 2009; Hasan 2010) have found strong evidence that company size is positively associated with the level of corporate social performance and disclosures. In this study, company size is determined by the amount of the paid capital of banking companies. Considering the real context of Bangladesh, the study assumes that larger companies with more capital are expected to perform fewer social activities as they are already established in the market while smaller companies may have a kind of urge to fulfil the stakeholders' expectations and attract a larger part of society through corporate social activities and reporting. Hence, the study hypothesises that:

$H_{5}$ : There is a significant negative association between company size and the level of corporate social disclosure.

This hypothesis is derived from the resource dependence perspective that assumes that established and big companies can have comparatively easy access to the external sources of resources, which, ultimately, may discourage them from fostering their CSR initiatives.

\section{Research Design}

\subsection{Sample and Data}

This research is mainly based on secondary data collected from the annual report of the concerned company. The period of data collection is for 5 years from 2011 to 2015. The data period from 2011 to 2015 is chosen because there was a Statutory Regulatory Order (SRO) in 2011 from the National Board of Revenue(NBR) of Bangladesh related to tax exemption for corporations for the amount of expenditure made on corporate social responsibility activities. Thirty banking companies listed on the Dhaka Stock Exchange (DSE) have been taken as the sample of the study. Although there are more than 50 banking companies operating in Bangladesh, this study only considers listed banking companies due to public accountability, which is a subject associated with voluntary non- 
financial reporting. Beyond public accountability, another important reason for incorporating 30 banking companies (all listed) is to ensure data consistency as it is very difficult to obtain data for non-listed companies, particularly in a very poor reporting environment like Bangladesh.

\subsection{Empirical Model Specification and Variables}

In this study, following pooled ordinary least squares (OLS) model is used to test the degree of association between company's internal factors and the extent of corporate social reporting:

$$
\begin{aligned}
S R D I= & \beta_{0}+\beta_{1} B S+\beta_{2} F N+\beta_{3} B M+\beta_{4} B E X P+\beta_{5} F S+\beta_{6} C R+\beta_{7} M C+ \\
& \beta_{8} L E V+€
\end{aligned}
$$

where,

$S R D I$ is the social responsibility disclosure index, which is expressed by the number of issues disclosed.

$B S$ is the board size, which shows the total number of directors on the board.

FN is the company network, which is represented by the number of branches of a banking company.

$B M$ means board meetings, which represents the total number of board meetings held in a year.

BEXP stands for board expertise, which indicates the professional expertise of the board members measured by the existence of a particular academic and professional degree.

FS stands for company size, which is measured by the size of the paid up capital of each company. The model has some control variables that are expected to have influence over the outcome of the model.

$C R$ stands for credit rating. This is measured by the rating point of each sample banking company as rated by the Credit Rating Agency of Bangladesh, which is measured as 3 for AAA meaning 'extremely strong', 2 for AA meaning 'very strong', and 1 for A meaning strong. $M C$ is the market category of share, which is measured 1 for ' $A$ ' category and 0 for ' $Z$ ' category.

$L E V$ is the leverage of the company, which is measured by the debt to equity ratio.

\subsection{Social Reporting Disclosure Index}

The Social Reporting Disclosure Index (SRDI) is the dependent variable of the current study, which has been constructed by the 31 disclosure 
issues. The disclosure items are consistent with the study of Jizi et al. (2014). The list of disclosure items is presented in the table in Appendix 1. In choosing the disclosure items, it has been kept in mind that all major areas regarding society and community are involved with disclosures. Content analysis has been utilised to construct the social reporting disclosure index, which is consistent with the study of Khan et al. (2012). Cochran and Wood (1984) mention that content analysis is an objective procedure. Each individual disclosure item has been checked in the annual report and is coded 1 for existence and 0 for nonexistence following the dichotomous procedure. Then, the total score has been calculated by counting the total number of disclosure items disclosed in the annual report of each banking company. Table 1 presents the proportionate disclosure items divided into four different categories.

Table 1. Categorical Distribution of the Social Disclosure Items

\begin{tabular}{|c|c|c|}
\hline Category & Number of Disclosures & Percentage \\
\hline Community & 6 & 19 \\
\hline Environment & 4 & 13 \\
\hline Employee & 3 & 42 \\
\hline Customers & 8 & 26 \\
\hline 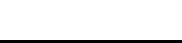 & 31 & 100 \\
\hline
\end{tabular}

\section{Empirical Tests and Results}

\subsection{Descriptive Statistics of the Dependent variable}

Table 2 presents the descriptive statistics of the Social Reporting Disclosure Index (SRDI), which is the dependent variable of the study.

Table 2. Descriptive Statistics of the Social Reporting Disclosure Index

\begin{tabular}{cccccc}
\hline Years & N & Mean & Std. Dev. & Min & Max \\
\hline 2011 & 29 & 7.724138 & 2.57594 & 0 & 11 \\
2012 & 30 & 8.533333 & 3.510903 & 0 & 17 \\
2013 & 30 & 8.7 & 3.69669 & 0 & 20 \\
2014 & 30 & 9.4 & 4.924254 & 2 & 26 \\
2015 & 30 & 8.333333 & 4.551115 & 0 & 17 \\
\hline Overall & 149 & 8.543624 & 3.930964 & 0 & 26 \\
\hline
\end{tabular}

From the table it is clear that a similar fashion is followed year after year to report almost similar items in the annual report by the companies. The results of the descriptive statistics of the social reporting disclosure items indicates a lower level of reporting, which is consistent with the study of Imam (2000). 


\subsection{Pearson Correlation Analysis}

Table 3 represents the Pearson Correlation Matrix, which shows the mutual relationship among the variables. The correlation among the variables is tested at the 10 per cent, 5 per cent, and 1 per cent significance level. The table shows that there is a positive correlation between board size (BS) and the social reporting disclosure index (SRDI). Another significant positive correlation is found between board meetings (BM) and company network (FN), which is .0001. Board expertise is positively correlated with social reporting disclosure index at .0001, meaning that expert board members can facilitate better social reporting. A significant negative correlation is found between company size and the social reporting disclosure index. Credit rating is not significantly correlated with any other explanatory variable. The variable market category $(\mathrm{MC})$ is positively correlated with board size, company network, and board meetings. Board size (BS) and company network (FN) are negatively correlated with leverage (LEV) at the 1 per cent significance level. In order to test whether multicollinearity exists between the independent variables of the model, the Variable Inflation Factor (VIF) test has been performed.

Table 3: Pearson Correlation Matrix

\begin{tabular}{llllllllll}
\hline & SRDI & $B S$ & $F N$ & $B M$ & $B E X P$ & $F S$ & $C R$ & $M C$ & $L E V$ \\
\hline SRDI & 1 & & & & & & & & \\
$B S$ & $.18^{* *}$ & 1 & & & & & & & \\
$F N$ & .1 & .12 & 1 & & & & & & \\
$B M$ & $.31^{* * *}$ & $.2^{* *}$ & $.31^{* * *}$ & 1 & & & & & \\
$B E X P$ & $.34^{* * *}$ & 0 & $.14^{*}$ & $.14^{*}$ & 1 & & & & \\
$F S$ & $-.26^{* * *}$ & .01 & .02 & .04 & $-.16^{* *}$ & 1 & & & \\
$C R$ & -.07 & .07 & .01 & .11 & .05 & -.08 & 1 & & \\
$M C$ & .02 & $.2^{* * *}$ & $.17^{* *}$ & $-.19^{* *}$ & .12 & .02 & .07 & 1 & \\
$L E V$ & .03 & $-.3^{* * *}$ & $-.23^{* * *}$ & -.12 & $.18^{* *}$ & $.24^{* * *}$ & $-.15^{*}$ & -.15 & 1 \\
\hline
\end{tabular}

Notes: The table represents the Pearson Correlation Matrix where SRDI $=$ Social Responsibility Disclosure Index, BS= Board Size, FN= Company Network, BM= Board Meetings, $\mathrm{BEXP}=$ Board Expertise, $\mathrm{FS}=$ Company Size, $\mathrm{CR}=$ Credit Rating, $\mathrm{MC}=$ Market Category, LEV= Leverage. Significance level 1\%,5\%, and 10\% are represented by ***, **, and * respectively.

The rule regarding the VIF test is that if the mean value of VIF is less than 10, then it indicates that no multicollinearity exists (Gujrati, 2003). The mean value of VIF is 1.25 , which means that no unacceptable multicollinearity exists between the explanatory variables. The detailed results of the VIF test are presented in Appendix 2. 


\subsection{Multivariate Regression Analysis}

To test the hypotheses that have been developed in this study, multivariate regression analysis has been conducted, which is shown in Table4. The application of multivariate regression in this study is validated by Roberts (1992), Chiu and Wang (2015) who also used similar instruments. In the regression model, the dependent variable is the Social Reporting Disclosure Index (SRDI). The independent variables are the key internal factors of companies that are considered to have a significant impact on the company's social disclosure level. There are a few control variables that are supposed to influence the regression outcome through their impact on the dependent variable. Pooled OLS, which is a very restrictive model compared to REM and FEM, has been used due to the lack of rigid estimation of the individual coefficients in the regression model.

Table 4. Multivariate Regression Result

\begin{tabular}{lcccc}
\hline Variables & $\begin{array}{c}\text { Predicted } \\
\text { Sign. }\end{array}$ & Coefficients & t-value & P-value \\
\hline Board Size (BS) & + & .1062587 & 1.38 & .171 \\
Company Network (FN) & + & .0001659 & -.05 & .957 \\
Board Meeting (BM) & + & .1597113 & 3.04 & $.003^{* * * *}$ \\
Board Expertise (BEXP) & + & .7234517 & 2.87 & $.005^{* * *}$ \\
Company Size (FS) & - & -.0003449 & -3.63 & $.000^{* * *}$ \\
Credit Rating (CR) & + & .9895107 & -1.68 & $.096^{*}$ \\
Market Category (MC) & + & -.8836232 & .5 & .614 \\
Leverage (LEV) & + & .1112028 & 1.24 & .217 \\
Constant ((B) & & 4.723678 & 1.13 & .26 \\
\hline
\end{tabular}

Notes: Table 4 presents the multiple regression results of the social responsibility disclosure index and company internal factors where the dependent variable is SRDI (Social Responsibility Disclosure Index).

Independent variables are $\mathrm{BS}=$ Board Size, $\mathrm{FN}=$ Company Network, BM= Board Meetings, BEXP = Board Expertise, and FS= Company Size.

Control variables are $\mathrm{CR}=$ Credit Ratings, $\mathrm{MC}=$ Market Category, and $\mathrm{LEV}=$ Leverage.

Significance level at $1 \%, 5 \%$, and $10 \%$ are represented by ${ }^{* * *},{ }^{* *}$, and ${ }^{*}$ respectively. In the model, R2 is .2691 and F is 6.03012 .

The results show that the Social Reporting Disclosure Index (SRDI) is positively associated with board size, company network, board meetings, board expertise, market category, and leverage. However, a negative association is found between the Social Reporting Disclosure Index (SRDI) and the company size and credit rating. The hypothesis that states a negative association between company size and social reporting disclosure is accepted as its $p$ value is .0000 , which is significant at the 1 per cent level of significance with a t-value of-3.63. The other hypothesis, which assumes that company network has a positive impact on social 
reporting disclosure, is rejected due to the large $p$ value, which means that a larger number of branches of a company do not ensure better corporate social activities and disclosures.

A positive relationship between board size and corporate social reporting was predicted in another hypothesis of the study. The regression result also shows a positive relationship between these two variables with a $t$-value of 1.38 , but a $\mathrm{p}$ value greater than $.10(\mathrm{p}=.171)$, which means the third hypothesis is rejected. This finding implies that the CSR disclosures level is not influenced by the number of board members of the company. The third hypothesis of the study predicted a positive association between the number of board meetings and corporate social reporting disclosures. The variable 'board meeting' has a $\mathrm{t}$-value of 3.04 with a $\mathrm{p}$ value of.003, and is significant at the 1 per cent level of significance; hence, we accept the hypothesis.

Another hypothesis of the study predicted that board expertise is positively related to corporate social reporting. This hypothesis is accepted as the regression model shows a $t$-value of 2.87 with a $p$ value of.005, which is significant at the 1 per cent level of significance. This is a crucial finding because it signals to stakeholders that the professional expertise of board members plays a big part in determining the degree of a company's corporate social reporting. The credit rating has a significant negative association with corporate social reporting disclosure with a $\mathrm{p}$ value of .096 . The relationship of market category and leverage with corporate social reporting is not statistically significant.

\section{Discussion and Policy Implications}

Due to the weak regulatory environment and lack of a notable presence of institutional investors, on-financial reporting in Bangladesh is going through a critical trial. The empirical results of this study show that banking companies have failed to take advantage of tax exemption on CSR expenditures circulated through SRO and that no significant development in corporate social disclosures happened between 2011 and 2015. Such a finding implies that it is very difficult, particularly in a reporting environment where CSR is practiced voluntarily, to motivate companies to initiate more CSR initiatives by only allowing tax exemption on CSR expenditures.

One possible reason for company's reluctance to voluntary undertake CSR practice to greater extent in Bangladesh is the absence of stakeholder pressure, particularly from the stock market. The multivariate regression results indicate that board meeting and board expertise have a significant positive impact on corporate social reporting. 
Such a result is consistent with a number of studies (see Alotaibi \&Hussainy, 2016; Benomran et al., 2015; Darus et al., 2015; Shamil et al., 2014). It is a clear indication that more frequent board meetings conducted by expert and efficient board members generate more initiatives that foster CSR activities and disclosures of companies.

A negative association between company size and corporate social reporting is predicted in the last hypothesis of the study and the hypothesis is not rejected. This result is consistent with Roberts (1992) where a similar negative association between company size and social disclosure level was found. The relationship between board size and corporate social reporting is positive but not significant, which results in the rejection of the very first hypothesis of the study.

This reveals that the number of board members does not have a notable impact in determining the degree and extent of CSR disclosures. The different dynamics of company internal factors are taken into consideration in this study, which acts as an important catalyst in determining the degree and quality of corporate social reporting, particularly in the banking industry.

\section{Conclusion}

The study has made a unique attempt to investigate the relationship and driving impact of company internal factors on the extent of corporate social reporting in the banking sector of an emerging economic nation, Bangladesh. In addition, the impact of a Statutory Regulation Order (SRO) by the National Board of Revenue (NBR), Bangladesh in 2011 relating to tax exemption on CSR expenditure is also investigated, which is another prime objective of this study. No notable impact of the government $\mathrm{SRO}$ in relation to tax exemption has been empirically proved, which signals that it is very difficult to pursue companies for greater CSR commitment and exposure, particularly when voluntary CSR reporting exists. In addition, based on the empirical results of the related hypotheses, the study has reached a conclusion that board meetings and board expertise have a significant positive impact on the corporate social reporting and that company size is negatively associated with company's CSR disclosures. This finding raises some implications for management like more frequent board meetings with professional expert board members yield better CSR practice and disclosures. This study is expected to have crucial implications and enrich the relevant CSR literature as academic implications have been assured through adopting a proper theoretical background and a review of the relevant CSR literature. The study has also made a noteworthy contribution in 
terms of management implications as it investigated the impact of company internal factors on company CSR activities and disclosure level.

\section{References}

Aguilera, R. V., Rupp, D. E., Williams, C. A., \& Ganapathi, J. (2007). Putting the S back in corporate social responsibility. A multilevel theory of social change in organizations. Academy of Management Review, 32, 836-863.

Aguilera, R. V., Williams, C. A., Conley, J. M., \& Rupp, D. E. (2006). Corporate Governance and Social Responsibility: A Comparative Analysis of the UK and the US. Corporate Governance: An International Review, 14(3), 147-158.

Azim, M. I., Ahmed, S., \& Islam, S. (2009). Corporate Social Reporting Practice: Evidence from Listed Companies in Bangladesh. Journal of Asia-Pacific Business, 10, 130-145.

Belal, A. R. (2001). A study of corporate social disclosures in Bangladesh. Managerial Auditing Journal, 16, 274-289.

Belal, A. R., \& D. L. Owen. (2007). The View of Corporate Managers on the Current State of, and Future Prospects for Social Reporting in Bangladesh. Accounting, Auditing and Accountability Journal, 20(3), 472-494.

Chen, C., \& Jaggi, B. (2000). Association between Independent Non-Executive Directors, Family Control and Financial Disclosures in Hong Kong. Journal of Accounting and Public Policy, 19, 285-31.

Chui, T. \& Wang, Y. (2015). Determinants of Social Disclosure Quality in Taiwan: An Application of Stakeholder Theory. Journal of Business Ethics, 129(2), 379398.

Das, S., Dixon, R., \& Micheal, A. (2015). Corporate Social Responsibility Reporting: A Longitudinal Study of Listed Banking Companies in Bangladesh. World Review of Business Research, 5(1), 130-154.

Davis, G. F. \& Cobb, J. A. (2010). Resource Dependence Theory: Past and Future. Newyork: NY, Emerald group Publishing, 21-42.

Deegan, Craig. (2002). Introduction the Legitimizing Effect of Social and Environmental Disclosures - A Theoretical Foundation, Journal of Accounting, Auditing and Accountability Journal, 15(3),282- 311.

Esa, E., \& Zahari, A. R. (2015). Corporate Social Responsibility: Ownership structures, Board Characteristics and the Mediating Role of Board Compensation, presented at $7^{\text {th }}$ International Economics and Business Management Conference, Pahang, Malaysia, $5^{\text {th }} \& 6^{\text {th }}$ October, 2015. Elsevier B.V.

Glanchant, J. (2002). Why regulate Deregulated Network Industries? Completion and Regulation in Network Industries, 3(3), 297-311.

Gray, R. (2001). Thirty Years of Social Accounting, Reporting and Auditing: What (If Anything) Have We Learnt? Business Ethics: A European Review, 10(1), 9-15.

Gray, R. H., Javad, M., Power, D. M., \& Sinclair, C. D. 2001. Social and environmental disclosure and corporate characteristics: a research note and extension, Journal of Business Finance and Accounting, 28, 327-356. 
Habek, P., \& Wolniak, R. (2015). Assessing the quality of corporate social responsibility reports: the case of reporting practices in selected European Union member states. Quality and Quantity, 2, 399-420.

Habek, P., \& Wolniak, R. (2015). Factors Influencing the Development of CSR Reporting Practices: Experts' versus Preparers' Points of View. Inzinerine Ekonomika-Engineering Economics, 26(5), 560-570.

Hamid, F. Z. A. (2004). Corporate Social Disclosure by Banks and Financial Companies Malaysian Evidence. Corporate Ownership and Control, 1(4), 118130.

Hermalin, B. E., \& Michael, S. W. (2003). Boards of directors as an endogenously determined institution: A survey of the economic literature. Economic Policy Review, 9, 7-26.

Hillman, A. J., Withers, M. C., \& Collins, B. J. (2009). Resource Dependence Theory: A Review. Journal of Management, 35 (6), 1404-1427.

Hossain, D. M., Khan, A. R., \& Yasmin, I. (2004). The Nature of Voluntary Disclosures on Human Resource in the Annual Reports of Bangladeshi Companies. Dhaka University Journal of Business Studies, 25(1), 221-231.

Hossain, M., Islam, K., \& Andrew, J. (2006). Corporate social and environmental disclosure in developing countries: Evidence from Bangladesh. working paper. Sydney, Australia: University of Wollongong, Faculty of Commerce.

Imam, S. (2000). Corporate social performance reporting in Bangladesh. Managerial Auditing Journal, 15, 133-141.

Jizi, M. I., Salama, A., Dixon, R., \& Stratling, R. (2013). Corporate Governance and Corporate Social Responsibility: Evidence from the US banking Sector. Journal of Business Ethics, 125(4), 601-615,

Kolk, A., \& Pinkse, J. (2010). The Integration of Corporate Governance in Corporate Social Responsibility Disclosures. Corporate Social Responsibility and Environmental Management, 17(1), 150-26.

Kor, Y. Y., \& Misangyi, V. F. 2008. Outside directors' industry-specific experience and firms' liability of newness. Strategic Management Journal, 29, 1345-1355.

Krasodomska, J. (2015). CSR disclosures in the banking industry. Empirical evidence from Poland. Social Responsibility Journal, 11(3), 406-423.

Naser, K., \& Hassan, Y. (2013). Determinants of corporate social responsibility reporting: evidence from an emerging economy. Journal of Contemporary Issues in Business Research, 2(3), 56-73.

Owen, D. L. (2005). Corporate social reporting and stakeholder accountability: the missing link. Accounting, Organizations and Society, 32, 649-67.

Parsa, S., \& Kouhy, R. (2008). Social Reporting by Companies Listed on the Alternative Investment Market. Journal of Business Ethics, 79(3), 345-360.

Paul, K., Cobas, E., Ceron, R., Frithiof, M., Maass, A., Navarro, I., \& Deaton, L. Z. (2006). Corporate social reporting in Mexico. Journal of Corporate Citizenship, 2006(22), 67-80.

Reverte, C. (2009). Determinants of Corporate Social Responsibility Disclosure Ratings by Spanish Listed Firms. Journal of Business Ethics, 88(2), 351-366. 
Roberts, R. W. (1992). Determinants of Corporate Social Responsibility Disclosure: An Application of Stakeholder Theory. Accounting, Organization and Society, 17, 595-612.

Sarker, A. A. (2000). Regulation of Islamic banking in Bangladesh: Role of Bangladesh Bank. International Journal of Islamic Financial Services, 2(1), 45-56.

Tagesson, T., Blank, V., Broberg, P., \& Collin, S. (2009). What Explains the Extent and Content of Social and Environmental Disclosures on Corporate Websites: A Study of Social and Environmental Reporting in Swedish-Listed Corporations? Corporate Social Responsibility and Environmental Management, $16(6), 352-364$.

Webb, E. (2004). An examination of socially responsible firms' board structure. Journal of Management and Governance, 8(3), 255-277.

$\mathrm{Wu}, \mathrm{M}$. \& Chung-Hua S. (2013). Corporate social responsibility in the banking industry: Motives and financial performance. Journal of Banking and Finance, 37, 3529-354. 


\section{Appendix 1:}

\begin{tabular}{|c|c|}
\hline Category & Disclosure Items \\
\hline Community & $\begin{array}{l}\text { SRD 1: Contributions and donations to charities, NGOs, and community } \\
\text { activities } \\
\text { SRD 2: Provision of support to students to continue their education and } \\
\text { sponsoring sport activities } \\
\text { SRD 3: Sponsoring health programmes } \\
\text { SRD 4: Sponsoring arts and culture } \\
\text { SRD 5: Supporting sports and/or recreational projects } \\
\text { SRD 6: Participation in social government campaigns }\end{array}$ \\
\hline Environment & $\begin{array}{l}\text { SRD 7: Bank's environmental policies and concerns } \\
\text { SRD 8: Implemented systems for environmental management } \\
\text { SRD 9: Environmental projects, such as recycling and protection of } \\
\text { natural resources } \\
\text { SRD 10: Energy saving in performing business operations }\end{array}$ \\
\hline Employee & $\begin{array}{l}\text { SRD 11: Number of employees; health and safety policies and measures. } \\
\text { SRD 12: Equal opportunities in employment (e.g., minorities, women) } \\
\text { SRD 13: Training and education provided to the employee } \\
\text { SRD 14: Employee assistance/benefits } \\
\text { SRD 15: Employee compensation } \\
\text { SRD 16: Employee expertise and backgrounds } \\
\text { SRD 17: Employee share purchase schemes } \\
\text { SRD 18: The confidence and self-esteem of employees } \\
\text { SRD 19: Employees' appreciation } \\
\text { SRD 20: Issues related to the recruitment process } \\
\text { SRD 21: Photos to document employee welfare } \\
\text { SRD 22: Discussion of employees' welfare } \\
\text { SRD 23: Policies adopted regarding staff profit sharing }\end{array}$ \\
\hline Customers & $\begin{array}{l}\text { SRD 24: Diversity of social products (e.g., climate products, educational } \\
\text { loans, etc.) } \\
\text { SRD 25: Discussion of the types of social products } \\
\text { SRD 26: Geographical distribution and marketing network of the offered } \\
\text { social products } \\
\text { SRD 27: Discussions in relation to customers' feedback } \\
\text { SRD 28: Provision for disabled, frail, and difficult-to-reach customers } \\
\text { SRD 29: Investments in social responsibility activities } \\
\text { SRD 30: Strategies and plans for future expansion in social products and } \\
\text { services } \\
\text { SRD 31: Loyalty programmes and gifts to customers }\end{array}$ \\
\hline
\end{tabular}


Appendix 2:

\begin{tabular}{|l|l|l|}
\hline Variable Name & VIF Score & Tolerance Level (1/VF) \\
\hline Board Size (BS) & 1.47 & .680891 \\
\hline Firm Network (FN) & 1.27 & .787857 \\
\hline Board Meeting (BM) & 1.26 & .794090 \\
\hline Board Expertise (BEXP) & 1.24 & .806292 \\
\hline Firm Size (FS) & 1.23 & .810295 \\
\hline Credit Rating (CR) & 1.23 & .812651 \\
\hline Market Category (MC) & 1.16 & .858644 \\
\hline Leverage (LEV) & 1.10 & .907072 \\
\hline Mean VIF & 1.25 & \\
\hline
\end{tabular}

